\title{
CONDITION OF CORAL AND REEF FISH IN THE LOCATION OF FISH CATCHING USING DYNAMITE FISHING IN KAPOPOSANG WATER PARK AND THE SURROUNDING SEA
}

\author{
Mahmudin $^{1 *}$, Chair Rani ${ }^{1}$, Hamzah $^{1}$ \\ Submitted: November 19, 2019 Accepted: February 24, 2020
}

\author{
${ }^{1}$ Department of Marine Science, Faculty of Marine Science and Fisheries, University of Hasanuddin \\ Corresponding Author: \\ *Mahmudin \\ Email: Mahmudin0704@gmail.com
}

\begin{abstract}
Dynamite fishing is one of the causes of damage to the coral reef ecosystem in Indonesia. Fishing activities using explosives (dynamite fishing) occur because of the desire of fishermen to get a lot of catch with low cost in a short time. Kapoposang Water Park (WP) is a region rich in marine biological resources. However, dynamite fishing activities which are still found within the area have caused the coral reef ecosystem to be severely damaged. The results showed a lower difference in the percentage of live coral cover at dynamite fishing locations (DF1, DF2) compared to control locations $(\mathrm{K} 1, \mathrm{~K} 2)$. In addition, the highest average values of coral fish abundance were found at locations $\mathrm{K} 1, \mathrm{DF} 1$, and DF2. Conversely, the results of the analysis found the lowest fish abundance at the K2 location. Different from the average number of reef fish species that were higher at the control location $(\mathrm{K} 1, \mathrm{~K} 2)$ compared to dynamite fishing locations (DF1, DF2). For the target fish biomass there is no real difference between the control location and dynamite fishing.

Keywords: Dynamite fishing, coral reef, kapoposang water park
\end{abstract}

\section{INTRODUCTION}

Coral reef ecosystem provides many benefits for humans and other marine biota. These benefits include as a place to look for food (feeding ground), a place of care (nursery ground), and a place of spawning (spawning ground). The many benefits provided by coral reef ecosystems lead to increased human dependence on these ecosystems. High dependence will put pressure on coral reef ecosystems such as destructive fishing practices, sedimentation and land-based pollution (burke et al. 2001).

Destructive fishing using explosives is one of the causes of damage to coral reef ecosystems in indonesia (Latuconsina, 2010; sala et.al, 2011; Satria, 2017). Prohibition of the explosives use has been contained in Law Number 27 of 2007 article 35 which states in the use of coastal areas and small islands, everyone is directly or indirectly prohibited from using explosives, toxic materials, and / or other materials that damage the coral reef ecosystem . In addition, Law Number 31 of 2004 in article 8 also explains that each person is prohibited from fishing and / or cultivating fish using chemicals, biological materials, explosives, tools and / or methods, and / or buildings that can harm and / or endanger the preservation of fish resources and / or the environment in the territory of the Republic of Indonesia fisheries management.
Kapoposang Water Park (WP) is a rich region in marine biological resources. (Hasrinda et.al 2012; Nessa, n. et al. 2014; Ministry Decision Number 59, 2014; Ali, 2017). Based on Ministry Decision Number 59 of 2014 the ecological potential possessed by Kapoposang island is the ecosystem of coral reefs, seagrass beds, and mangroves. However, Dynamite Fishing activities which were still found within the area have caused the coral reef ecosystem to suffer heavy damage with percent coverage of $25-40 \%$ where the worst damage was at a depth of 0-10 meters (Faizal and Jompa, 2010). Likewise with the results of a coral reef health monitoring survey by COREMAP II in August 2011 , it was stated that the condition of the coral reef ecosystem of the WP in the Kapoposang islands and surrounding seas was generally damaged. Therefore, the purpose of this research was to analyze the condition of coral reefs and reef fish in areas that experience and areas that do not experience fishing exploitation using explosives.

\section{MATERIALS AND METHODS}

The research was conducted in January - August 2019 in the Kapoposang Water Park and the surrounding Sea. The tools and materials used in this study include: (1) Meters, (2) Scuba equipment, (3) Underwater cameras, (4) Slate, (5) Boats and (6) Global Positioning System (GPS) 


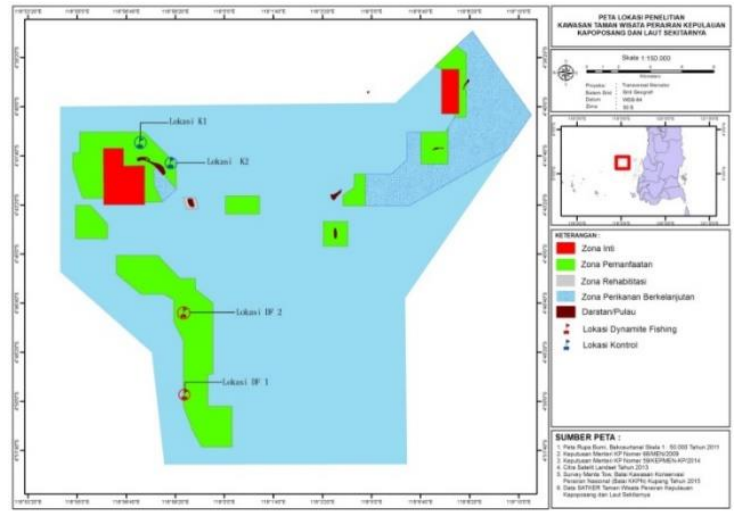

Figure 1. Map of the Research Location in the Kapoposang Water Park and the Surrounding Sea

\section{Coral Reefs Condition}

Data collection of the coral reefs condition used the underwater photo transect method (UPT) which was done by underwater digital photography or ordinary digital cameras completed with protectors for underwater use (housing). Observation of coral reefs was carried out at Dynamite fishing locations (DF1, DF2) and Control locations (K1, K2). Transects were installed at a depth of 7 meters with 3 replications each. The length of transect at each test was 50 meters with a distance between 5 meters.

\begin{tabular}{|c|c|c|c|c|}
$\begin{array}{c}\text { Transect Length } \\
\text { Replication 1 }\end{array}$ & Interval & $\begin{array}{c}\text { Transect Length } \\
\text { Replication 2 }\end{array}$ & Interval & $\begin{array}{c}\text { Transect Length } \\
\text { Replication 3 }\end{array}$ \\
\hline $50 \mathrm{~m}$ & $5 \mathrm{~m}$ & $50 \mathrm{~m}$ & $5 \mathrm{~m}$ & $50 \mathrm{~m}$
\end{tabular}

Figure 2. Sketch of retrieval of data collection on the condition of coral reefs and the extent of dead coral cover (rubble) at the fishing location using explosive materials and control

\section{Abundance And Biomass Of Coral Fish}

Identification of reef fish species was carried out using the Underwater Visual Census (UVC) method. This method is best used for data collection on fish species and the number of individual fish (English et al. 1994).

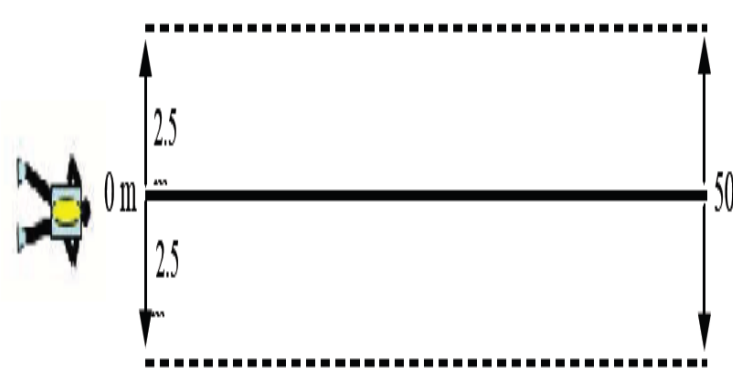

Figure 3. Recording the abundance and biomass of the Coral Fish (target fish) using the Underwater Visual Census method (English et al. 1997)
Transects were installed at a depth of 7 meters at the predetermined observation station based on Dynamite fishing locations (DF1, DF2) and control locations (K1, K2) with 3 replications each. The transect length at each test was 50 meters with a distance between 5 meters.In addition, information about the estimated total length of target fish and the number of individual fish in the long range was also obtained from this observation. The estimated total length of fish obtained will then be used to estimate the weight of the target reef fish.

\section{Data Analysis}

The percentage of life-form cover results obtained is presented descriptively with a table or graph so that coral quality can be determined by referring to Minister of Environment Decree No. 4 of 2001. In addition, to see differences in the percentage of coral cover at each observation station used a oneway ANOVA analysis (Steel and Torrie, 1993). The calculated data will be presented in the form of a histogram graphic which is processed using SPSS 16.0 software.

Table 1. Standard Criteria for Coral Damage based on Minister of the Environment Decree No. 4 of 2001

\begin{tabular}{lll}
\hline Criteria & & $\begin{array}{l}\text { Coral Cover } \\
\text { Percentage }(\%)\end{array}$ \\
\hline \multirow{2}{*}{ Damage } & Bad & $0-24,9$ \\
& Medium & $25-49,9$ \\
\multirow{2}{*}{ Good } & Good & $50-74,9$ \\
& Very Good & $75-100$ \\
\hline
\end{tabular}

Abundance is the individual number of all reef fish species per tribe per observation area.

Abundance $=\frac{\sum \text { Individuals } \text { (Target Fish, Indicators, Major, each family) }}{\text { Observation Transect Area }\left(250 \mathrm{~m}^{2}\right)}$

The length-weight relationship is used to determine the total biomass at each observation location. Size estimated will be converted to biomass estimation by using a known length-weight relationship for each species using the formula:

$$
\begin{gathered}
W=a \times \text { Lb } \\
B T=\frac{\sum \text { Total Weight of Target Fish }(W)}{\text { Observation Transect Area }}
\end{gathered}
$$

Where: $\mathrm{W}=$ Fish Wight in $(\mathrm{g}) ; \mathrm{L}=$ Fish Length in $(\mathrm{cm})$; and $\mathrm{a}$ and $\mathrm{b}$ are constant values calculated for each species or genus. Total biomass $\left(\mathrm{Bkg} / \mathrm{m}^{2}\right)$ is the total weight of the target fish (W) per unit area of the observation area. For the estimated values of $\mathrm{a}$ and $\mathrm{b}$ constants for each target reef fish species refer to Kulbicki et al. (2005) and Green and Bellwood (2009). 


\section{RESULTS AND DISCUSSION}

\section{Coral Reefs Condition}

Based on the data analysis results, the percentage of coral cover showed significant results. This can be interpreted, that all categories of coral cover differ at each observation site. The results of data analysis showed the highest average percentage of live coral cover was in $\mathrm{K} 2$ location at $25.78 \%$. If referring to the standard criteria for damage to coral reefs Minister of Environment Number 4, then the condition of coral reefs in these locations is classified as Medium. However, in the dead coral category, K2 location also has a high value compared to other locations. The high value of dead coral at these locations was thought to be caused by predation of Acathaster plancii. The same thing can be seen from the results of biophysical monitoring conducted by the management showing a decrease in the condition of coral reefs at a depth of $7-12$ meters caused by predation of Acathaster plancii in 2006 - 2010 (WP of Kapoposang, 2017).

Meanwhile, the lowest percentage of live coral cover was found in the DF2 location with a value of $8 \%$. If referring to the standard criteria for damage to coral reefs Minister of Environment Number 4, then the condition of coral reefs at these locations was classified as Poor. The low live coral cover at the DF2 location was presumably due to the use of explosives in fishing. As revealed by Ali (2017) and Faizal and Jompa (2010) who found the condition of dead coral at several observation points on Kapoposang Island showed damage due to human activities in the form of the use of explosives (Bombs). This condition was indicated by the large number of rubble and dead coral.

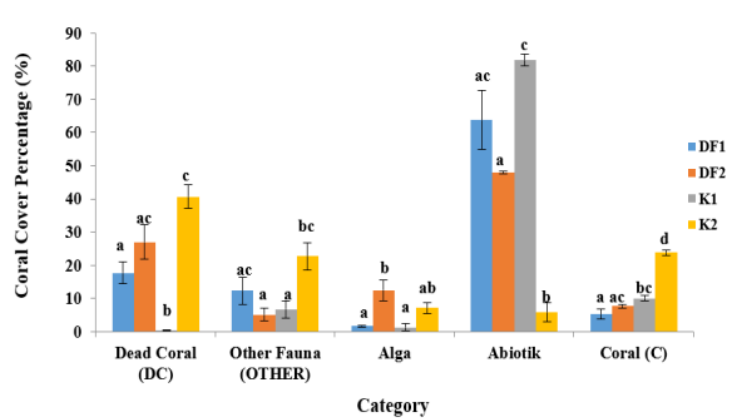

Figure 5. Coral Cover Percentage in depths of 7 meters

\section{Number of Types of Coral Fish}

During the research, 76 species of reef fish were found from 15 families. The results of data analysis also showed a real difference between the average number of reef fish species between K1 and DF2 locations. Location K1 was the location that had the highest average number of reef fish species. The reef fish species of the Acanthuridae family were fish species that dominated at that location. According to Dwiponggo (1982) the species of reef fish from the family Acanthuridae was the most commonly seen and living group of fish on a coral reef.

In contrast, the lowest average number of reef fish species was found in the DF2 Dynamite fishing location. At this location the fish species of the Acanthuridae family were also the dominant fish species. However, if compared to the value of the number of fish species of the family Acanthuridae in the DF2 location was much less than the K1 location. The low value of the Acanthuridae family fish species in the DF2 location was suspected, because the fish were the main target of Dynamite fishing. In accordance with the results of research conducted by Onthoni et.al (2009) that the operation of fish bombs in fishing, carried out in secret, or carried out when finding a horde of fish.

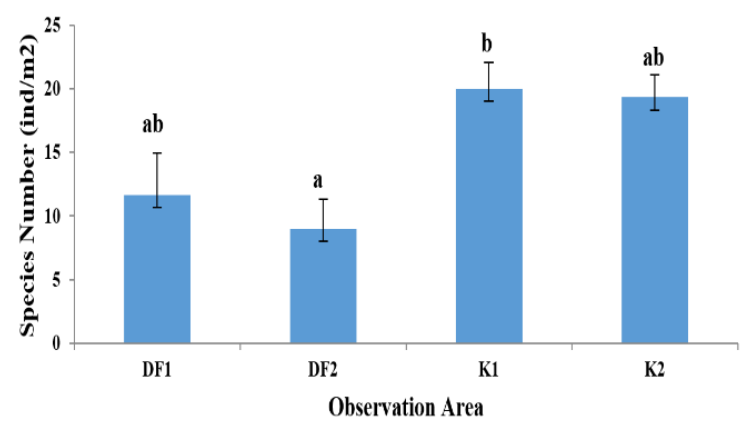

Figure 6. Average number of reef fish species (Species / $\left.250 \mathrm{~m}^{2}\right)$ at all observation areas

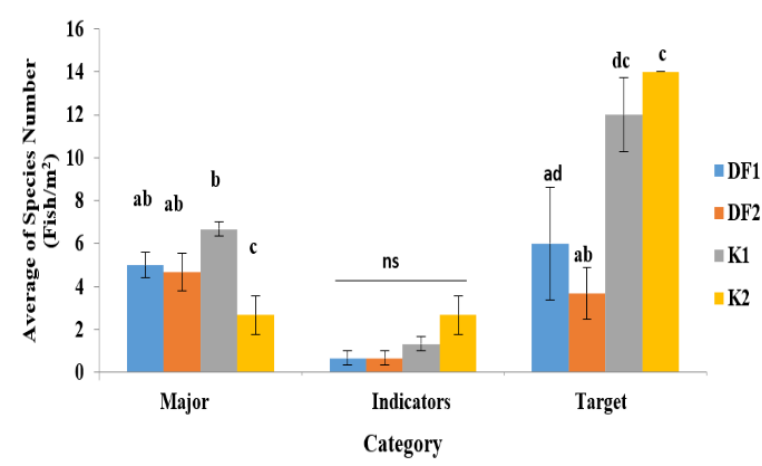

Figure 7. Average number of reef fish species (Fish / 250 $\mathrm{m}^{2}$ ) at each observation areas based on Major Fish, Indicator, and Target categories.

Based on the fish category, there was a significant difference in the average value of the target fish species number in the DF2 location with $\mathrm{K} 1$ and $\mathrm{K} 2$. This difference can be seen from the number of target fish species at locations $\mathrm{K} 1$ and $\mathrm{K} 2$ which were classified as higher compared to locations DF1 and DF2. The low number of species at the DF2 location was thought to be due to the high intensity of fishing using Dynamite which made the target fish as the main catch. 
The results of the analysis also showed that the major fish categories were significantly different in the control locations $\mathrm{K} 1$ and $\mathrm{K} 2$. At K1 location, 11 major fish species from 4 families were found, namely Balistidae, Ephippidae, Labridae, and Zanclidae. In contrast, in the K2 location, only 5 major fish species from 3 families were found, namely Pomacanthidae, Pomacentridae, and Zanclidae. Special types of major fish from the family Pomacentridae were not found at location $\mathrm{K} 1$. This was thought to be due to the low algae at that location which was the main food of the family Pomacentridae fish species. According to Randall et al. (1990) Pomacentridae is a well-known herbivore fish that eats algae and plankton.

Meanwhile, the analysis results for the indicator fish category showed no significant difference at all observation locations. This can be interpreted that the number of species of indicator fish at all observation locations is the same.

\section{Abundance of Coral Fish}

Based on the analysis results showed a real difference in the abundance of reef fish between locations DF1, DF2, K1 with locations K2. The difference can be seen from the difference in the average abundance of reef fish between these locations. The highest abundance was found at location K1 with an average value of 227 species / $250 \mathrm{~m}^{2}$. This value was much higher when compared to the abundance of reef fish at the K2 location with an average value of 49 species / 250 $\mathrm{m}^{2}$.

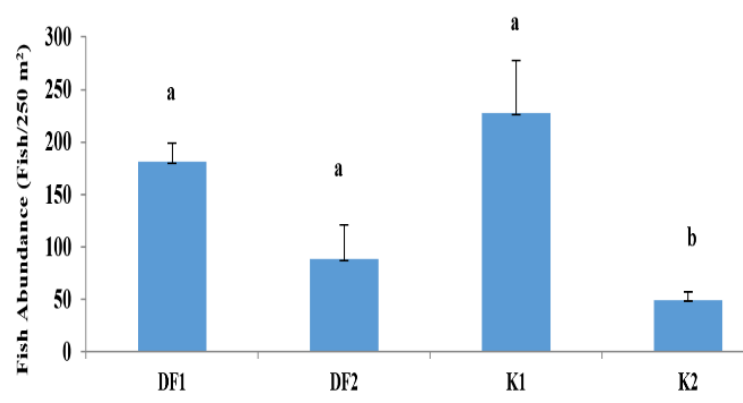

Figure 8. Abundant Average of Reef Fish in all observation areas.

The low abundance of fish in the K2 location was presumably due to the form of coral growth dominated by massive corals and Mushroom causing minimal space for reef fish to live. Different things were found in the $\mathrm{K} 1$ location which was dominated by Acropora branching corals so that there was enough space for reef fish to live. According to Muniaha et.al (2016) more branched corals provide more space for other organisms thereby increasing the diversity of coral reef substrate forms.

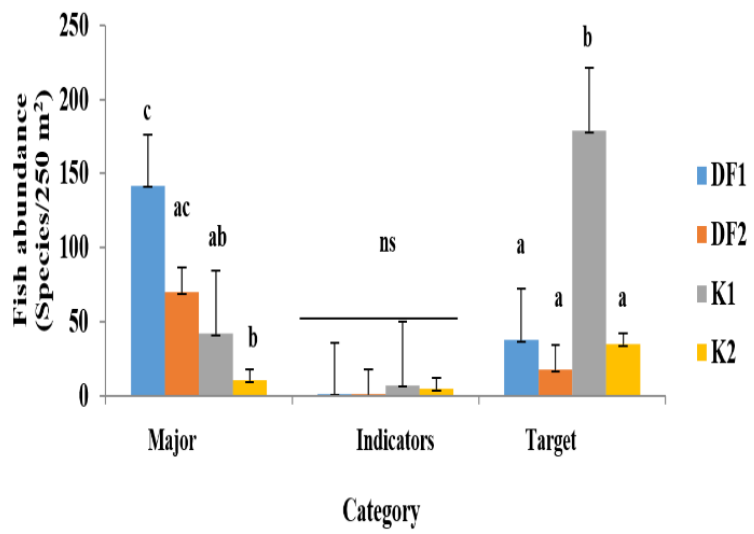

Figure 9. Average abundance of Reef Fish at all Observations by Major Fish, Indicator and Target Categories.

Based on the reef fish category, there were significant differences in the average value of major fish abundance in DF2 locations with $\mathrm{K} 1$ and $\mathrm{K} 2$. The highest abundance of major fish was found in DF1 location with an average value of 142 species / $250 \mathrm{~m}^{2}$. This value is much higher compared to the average value of abundance of reef fish at location $\mathrm{K} 1$ with a value of 42 species / $250 \mathrm{~m}^{2}$ and $\mathrm{K} 2$ with a value of 10 species / $250 \mathrm{~m} 2$ ). The major reef fish species that dominated in the DF1 location were the family Pomacentridae and Balistidae. The high value of fish abundance from the Pomacentridae family at the DF1 location was thought to be due to the high cover of dead coral overgrown with algae which was the main food of the fish species. These observations were in line with the study results of Rani et al. (2011) who found reef fish from the family Pomacentridae was the most dominant group on Barranglompo Island due to the abundance of algal micro-habitats and macro-algae as food.

Meanwhile, the analysis results of the target fish category showed significant values between locations $\mathrm{K} 1$ and $\mathrm{K} 2$, DF1, and DF2. The difference can be seen from the average value of the abundance of target fish where K1 location was the highest when compared to other locations. The average value of target fish abundance at $\mathrm{K} 1$ location was 179 ind $/ 250 \mathrm{~m}^{2}$. The target reef fish species that dominated at that location were the Acanthurus olivaceus species of the Acanthuridae family. The high abundance of target fish from the Acanthuridae family at K1 location was presumably due to the condition of the coral reefs which were still in good condition so that it supported the Acanthurus olivaceus species for life.

Meanwhile, the analysis results for the indicator fish category showed no significant difference at all observation locations. This can be interpreted that the number of indicator fish species at all observation locations is the same. 


\section{Coral Fish Biomass (Target Fish)}

Based on the analysis results showed no significant difference in the target fish biomass at all observation locations. At the location of DF1, Ctenochaetus striatus fish was a type of fish that dominated with an average value of $1456 \mathrm{gr} / 250 \mathrm{~m}^{2}$. The location of DF2 was dominated by Acanthurus olivaceus fish species with an average value of 3496 $\mathrm{gr} / 250 \mathrm{~m}^{2}$. Meanwhile, in the K1 location Caesio teres fish species dominated with an average value of $4630 \mathrm{gr} / 250 \mathrm{~m}^{2}$ and the $\mathrm{K} 2$ location was dominated by Plectorhinchus chaetodontoides fish with an average value of $1711 \mathrm{gr} / 250 \mathrm{~m}^{2}$

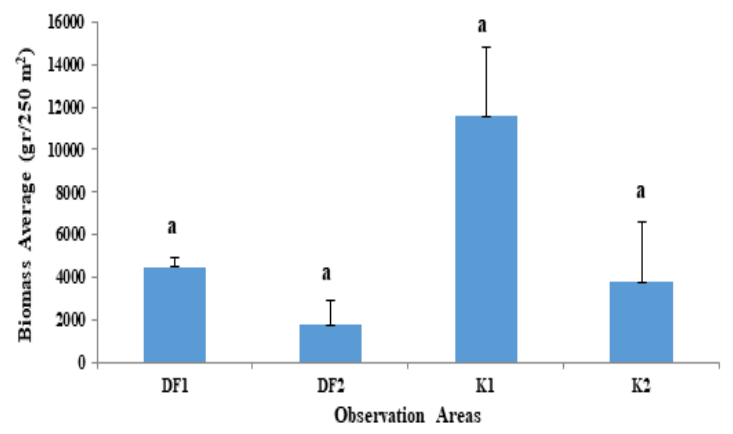

Figure 10. Biomass average of reef fish (Target Fish) at all observation sites.

Based on observations, it was found the fish length at all locations was not much different. Fish length at all observation sites ranged from $10-26 \mathrm{~cm}$. However, when comparing control locations with Dynamite fishing, the Dynamite fishing locations still had an average fish length slightly higher compared to control locations.

Table 2. Average reef fish biomass based on target fish families at all observation areas

\begin{tabular}{clllll}
\hline \multirow{2}{*}{ No } & \multirow{4}{*}{ Family } & \multicolumn{5}{c}{ Biomass Average $\left(\mathrm{gr} / 250 \mathrm{~m}^{2}\right)$} \\
\cline { 3 - 6 } & & \multicolumn{3}{c}{ Observation Areas } \\
\cline { 3 - 6 } & & DF1 & DF2 & K1 & K2 \\
\hline 1 & Acanthuridae & 2864 & 4723 & 2654 & 2192 \\
2 & Caesionidae & - & - & 7111 & - \\
3 & Lutjanidae & 48 & 59 & 262 & 626 \\
4 & Scaridae & 978 & 153 & 835 & 432 \\
5 & Nemiptiridae & 73 & - & 278 & - \\
6 & Siganidae & 348 & 55 & 15 & 478 \\
7 & Haemulidae & 215 & - & - & - \\
8 & Lethrinidae & - & - & - & 63 \\
\hline \multicolumn{2}{l}{ Source: Primary Data, 2019} & & &
\end{tabular}

\section{CONCLUSION}

Ecological impacts of coral reef ecosystems due to fishing using explosives (Dynamite fishing) include: A higher percentage of live coral cover was found in location $\mathrm{K} 2$ with an average value of live coral cover of $25.78 \%$ belonging to the medium category. Meanwhile, for locations K1, DF1, and DF2 which had an average value of the percentage of live coral cover ranging from 5.29 - 10, 04\% were included in the damaged category.

In general, the average number of reef fish species is higher in locations where coral reefs that are not exploited by explosives compared to reef sites that are exploited by fishing for explosives (Dynamite fishing). Meanwhile, for the highest abundance of reef fish found at location $\mathrm{K} 1$ with an average value of 227 species / $250 \mathrm{~m}^{2}$. However, the K2 abundance value was lower compared to the location of DF1 and DF2 which were in the location of coral reefs exploited by explosives fishing. For the target fish biomass there was no real difference between the control location and Dynamite fishing.

\section{PREFERENCES}

Ali, S.N. 2017. Perkembangan Kondisi Terumbu Karang Di Pulau Kapoposang Tahun 20092015 Kabupaten Pangkep. Skripsi. Makassar. Fakultas Ilmu Kelautan dan Perikanan Universitas Hasanuddin.

Burke, L. et. al. 2001. Terumbu Karang yang Terancam di Asia Tenggara (Ringkasan Untuk Indonesia). www.reefcheck.or.id/.../terumbu-karangyang-terancam-di-... Diunduh 15 maret 2018.

Dwiponggo, A. 1982. Pengkajian Sumberdaya Perikanan dan Tingkat Pengusahaannya di Perairan Sulawesi Selatan. Laporan Penelitian. Balai Penelitian Perikanan Laut. Jakarta.

English, S. et. al.1997. Surveymanual for tropical marine resources Townsville:Australian Institute of Marine Science.

Keputusan Menteri Kelautan dan Perikanan Republik Indonesia Nomor 59 tahun 2014 tentang Rencana Pengelolaan dan Zonasi Taman Wisata Perairan Kepulauan Kapoposang dan Laut Sekitarnya di Provinsi Sulawesi Selatan Tahun 2014-2034. 2014. Jakarta. Kementerian Kelautan dan Perikanan Republik Indonesia.

Haslindah. 2012. Valuasi Ekonomi Ekosistem Terumbu Karang Taman Wisata Perairan Kapoposang Kabupaten Pangkep. Tesis. Makassar. Program Pascasarjana Universitas Hasanuddin

Huda AR. 2008. Kondisi Terumbu Karang di Sekitar Pelabuhan dan Non Pelabuhan di 
Perairan Pulau Kelapa dan Pulau Harapan, Kepulauan Seribu. [SKRIPSI]. Bogor: Program Studi Teknologi dan Ilmu Kelautan, Fakultas Perikanan dan Ilmu Kelautan, Institut Pertanian Bogor.

Faizal, A dan Jompa, J, 2010. Model Elevasi Digital Untuk Mendeteksi Kerusakan Terumbu Karang di Taman Wisata Alam Laut Kapoposang Sulawesi Selatan. Journal Ilmu Kelautan. Volume 1, 1-12.

Latuconsina, H. 2010. Identifikasi Alat Penangkapan Ikan Ramah Lingkungan di Kawasan Konservasi Laut Pulau Pombo Provinsi Maluku. Jurnal Ilmiah agribisnis dan Perikanan (agrikan UMMU-Ternate), Volume 3 Edisi 2.

Muniaha, H. et al. 2009. 2016. Studi kelimpahan ikan karang berdasarkan kondisi terumbu karang di Desa Tanjung Tiram Kabupaten Konawe Selatan. Jurnal Manajemen Sumber Daya Perairan, Volume 9-19. Kendari

Nessa, N. e al. 2014. Valuasi Ekonomi Ekosistem Terumbu Karang. USAID From The American People.

Randall, J.E. et. al. 1990. Fishes of the Great Barrier Reef and Coral Sea. University of Hawaii Press, Honolulu. 506h.
Rani, C. et. al. 2011. Sebaran dan Keanekaragaman Ikan Karang di Pulau Barrangloppo : Kaitannnya Dengan Kondisi dan Kompleksitas Habitat. Fakultas Kelautan dan Imu Kelautan, Universitas Hasanuddin. Makassar. 12 hal.

Sala, R.et. al. 2011. Destruktive fishing in coremap II area Raja Ampat. Journal of Indonesia coral reefs. 1: 30-40.

Satria, A. 2017. Destructive Fishing. Presentasi disajikan dalam Rapat Koordinasi Nasional Satuan tugas 115. Jakarta, 12 juli.

Undang-Undang Republik Indonesia Nomor 31 Tahun 2004 Tentang Perikanan. Jakarta. Kemeterian Kelautan dan Perikanan Republik Indonesia

Undang-Undang Republik Indonesia Nomor 27 Tahun 2007 Tentang Pengelolaan Wilayah Pesisir Dan Pulau-Pulau kecil. Jakarta. Kementerian Kelautan dan Perikanan Republik Indonesia

Keputusan Menteri Lingkungan Hidup Republik Indonesia Nomor 4 Tahun 2001 tentang Kriteria Baku Kerusakan Terumbu Karang. 2001. Jakarta. Kementerian Lingkungan Hidup Republik Indonesia. 